\title{
Prevalence of Oestrus ovis (Diptera: Oestridae) in sheep from the Sáo Paulo Central region, Brazil
}

\author{
Prevalência de Oestrus ovis (Diptera: Oestridae) em ovinos da região Central de São Paulo, Brasil \\ Bruna Fernanda da Silva ${ }^{1 *}$; Gustavo Puglia Machado; \\ Thiago Braga Izidoro ${ }^{2}$; Alessandro Francisco Talamini do Amarante ${ }^{1}$
}

${ }^{1}$ Departamento de Parasitologia, Instituto de Biociências, Universidade Estadual Paulista - UNESP, Botucatu, SP, Brasil

${ }^{2}$ Departamento de Higiene Veterinária e Saúde Pública, Faculdade de Medicina Veterinária e Zootecnia,

Universidade Estadual Paulista - UNESP, Botucatu, SP, Brasil

Received February 1, 2012

Accepted November 6, 2012

\begin{abstract}
The heads of 139 slaughtered sheep were examined with the aim of determining Oestrus ovis prevalence and infestation intensity in the central region of the State of São Paulo, Brazil. Heads from slaughtered sheep were examined and the first (L1), second (L2) and third (L3) O. ovis larval instars were recovered from the nasal and sinus cavities. O. ovis larvae were detected in $13.7 \%$ of the sheep analyzed. The monthly mean intensity of infestation ranged from 1 to 10.2 larvae per infested head, with general mean intensity of 4.5 larvae/infested head. Of the total of 85 larvae, $21.2 \%$ were $\mathrm{L} 1,37.6 \% \mathrm{~L} 2$ and $41.2 \% \mathrm{~L} 3$. In conclusion, all different $O$. ovis larvae instars were recovered from slaughtered animals, which demonstrates the existence of favorable climatic conditions for the fly activity and larval development of O. ovis in sheep raised in the Central region of the State of São Paulo.
\end{abstract}

Keywords: Oestrus ovis, sheep, prevalence.

\section{Resumo}

Com o objetivo de determinar a prevalência e intensidade de infestação por larvas de Oestrus ovis na regiáo Central do Estado de São Paulo, 139 cabeças de ovinos obtidas de um abatedouro foram examinadas. As larvas O. ovis foram recuperadas da cavidade nasal e seios frontais, identificadas de acordo com o estádio larval e quantificadas. As larvas de O. ovis foram detectadas em $13,7 \%$ das cabeças examinadas e a intensidade média mensal de infestação variou entre 1 a 10,2 larvas/cabeça infestada, com média geral de 4,5 larvas/cabeça infestada. Do total de 85 larvas recuperadas, 21,2\% eram larvas de primeiro estádio (L1), 37,6\% de segundo (L2) e 41,2\% de terceiro (L3). Em conclusão, todos os diferentes instares larvais de $O$. ovis foram recuperados de animais abatidos, o que demonstra a existência de condiçôes climáticas favoráveis para a atividade da mosca bem como o desenvolvimento larval em ovinos criados na regiáo Central do Estado de São Paulo.

Palavras-chave: Oestrus ovis, ovino, prevalência.

\section{Introduction}

Oestrus ovis (Diptera: Oestridae), the sheep nasal bot fly, is a cosmopolitan parasite whose larvae develop in the head sinuses and nasal passages of sheep and goats in all sheep-farming areas worldwide. The female fly is viviparous and deposits larvae in or around the nostrils of its host; these early first instars attach to the mucous membrane inside the nasal cavities, change to second instars, and move up to the sinuses where they develop into mature third instars, which are expelled by pupation in the soil (ZUMPT, 1965). The duration of this parasitic portion of the

${ }^{*}$ Corresponding author: Bruna Fernanda da Silva

Departamento de Parasitologia, Instituto de Biociências, Universidade Estadual Paulista - UNESP, Distrito de Rubiáo Júnior, s/n, CEP 18618-970, Botucatu,

SP, Brasil

e-mail: brusilvabio@gmail.com life cycle varies considerably: from a few weeks to several months, depending on the season and climatic conditions (COBBETT; MITCHELL, 1941). Clinical respiratory signs such as seromucous or purulent nasal discharge, frequent sneezing, and dyspnea may severely impair the health of affected animals (DORCHIES et al., 1998).

O. ovis can thrive in different environments and has adapted to the climate prevailing wherever sheep are kept (HORAK, 1977), and this ability to adapt to different environments allows for the natural persistence of infestation and makes it difficult to control it (ALCAIDE et al., 2005). Several researches have demonstrated the high prevalence of ovine oestrosis in numerous areas all over the world, e.g. Zimbabwe (PANDEY, 1989), France (YILMA; 
DORCHIES, 1991), Italy (CARACAPPA et al., 2000), Spain (ALCAIDE et al., 2003) and Greece (PAPADOPOULOS et al., 2010). Oestrosis is commonly found in sheep in Brazil, but there are few studies on the epidemiology of this parasite and most of them are restricted to the south region of the country, where favorable climatic conditions are observed throughout the year. The prevalence of oestrosis in sheep was of $85.4 \%$ in Bagé (RIBEIRO et al., 1990) and in Encruzilhada do Sul, both in the State of Rio Grande do Sul; the mean intensity of infestation was 23.8 larvae (OLIVEIRA et al., 1999). In the State of Santa Catarina, $O$. ovis infestation intensity was greater during the spring and summer months and no larvae were recovered from tracer sheep when the temperature was lower than $9{ }^{\circ} \mathrm{C}$ (RAMOS et al., 2006).

The first study on $O$. ovis epidemiology in the State of São Paulo was carried out recently in Botucatu, where prevalence was $50 \%$ with mean intensity of 16.8 larvae per animal, with higher infestation rates during spring and summer (SILVA et al., 2012). The State of São Paulo presents different climatic conditions in each of its regions and small sheep farms are found in most areas of this State. Therefore, detailed research on the epidemiology of parasitic infestation is required to recommend the best strategies of oestrosis prophylaxis in small ruminants. This study aimed to determine $O$. ovis prevalence in slaughtered sheep from five counties of Central region of the State of São Paulo, Brazil.

\section{Materials and Methods}

The heads of 139 slaughtered sheep were examined from July 2009 to February 2010. The animals were originated from Itápolis, Ibitinga, Borborema, Guarantã and Tapinas, municipalities in the Central region of the State of São Paulo. The monthly amount of sheep slaughtered in an abattoir in the municipality of Itápolis was variable and the heads of all slaughtered animals were examined. Most of the sheep were $\leq 1$ year old $(89.2 \%)$, with predominance of Santa Ines breed $(80.6 \%)$ and its crosses with Dorper breed. Information on prior antiparasitic treatment and sheep management were not available.

Climate data from Itápolis were obtained from a study performed by the Center of Meteorological and Climate Research Applied to Agriculture (CEPAGRI, 2012).
The heads of the slaughtered sheep were separated from the carcasses, put into individual plastic bags to avoid transfer of larvae from one head to another and to collect those that came out of the nasal cavities. They were transported to the laboratory inside a cool box with ice. The heads were cut open along their longitudinal and sagittal axes. All larvae present in the nasal cavity (nasal passage, septum, middle meatus and conchae) and paranasal sinus (frontal and maxillary) were carefully examined; all larvae found were collected and counted. The larvae were preserved in $70 \%$ alcohol and identified according to their stage of development based on the descriptions by Zumpt (1965) and Capelle (1966).

\section{Statistical analyses}

Spearman's rank correlation coefficient was estimated between larval burden and climatic conditions (mean temperature and rainfall) using Minitab release 11 .

Descriptive statistical analyses were performed in agreement with Bush et al. (1997). The following terms were used:

Prevalence: the number of hosts infested with $O$. ovis larvae divided by the number of hosts examined;

Intensity of infestation: the number of $O$. ovis larvae in a single infested host;

Mean intensity of infestation: the total number of $O$. ovis larvae found divided by the number of hosts infected with that parasite.

\section{Results}

The maximum and minimum amount of heads examined per month was 26 in July and August 2009 and 9 in October 2009, respectively. Of the 139 heads examined, 19 (13.7\%) were infested with $O$. ovis larvae with minimum and maximum prevalence of the 7.7\% in August 2009 and $20.0 \%$ in February 2010, respectively (Table 1 ). No O. ovis larva was recovered in October 2009, coinciding with the lowest number of heads examined. The monthly mean intensity of infestation ranged from 1 to 10.2 larvae per infested head, with general mean intensity of 4.5 larvae per infested head. Means of temperature and rainfall in Itápolis are presented in Table 2. The average annual rainfall

Table 1. Number of heads infested with Oestrus ovis per month, mean larval burden per head, number of first, second and third larval stages (L1-L3) and total number of larvae found per month in sheep from the Central region of the State of São Paulo, Brazil.

\begin{tabular}{|c|c|c|c|c|c|c|c|}
\hline Month & $\begin{array}{c}\text { Number of heads } \\
\text { examined }\end{array}$ & $\begin{array}{c}\text { Number of heads } \\
\text { infested }\end{array}$ & Prevalence (\%) & Mean larval burden & L1 & L2 & L3 \\
\hline July /2009 & 26 & 5 & 19.2 & 10.2 & 17 & 19 & 15 \\
\hline Aug. /2009 & 26 & 2 & 7.7 & 2.0 & 0 & 0 & 4 \\
\hline Sept. /2009 & 13 & 2 & 15.4 & 1.0 & 0 & 0 & 2 \\
\hline Oct. $/ 2009$ & 9 & 0 & 0 & 0 & 0 & 0 & 0 \\
\hline Nov. /2009 & 12 & 1 & 8.4 & 4 & 0 & 0 & 4 \\
\hline Dec. /2009 & 16 & 3 & 18.8 & 4.7 & 1 & 9 & 4 \\
\hline Jan. /2010 & 17 & 2 & 11.8 & 1.0 & 0 & 0 & 2 \\
\hline Feb. $/ 2010$ & 20 & 4 & 20.0 & 2.0 & 0 & 4 & 4 \\
\hline Total & 139 & 19 & & & 18 & 32 & 35 \\
\hline Mean & & & 13.7 & 4.5 & & & \\
\hline
\end{tabular}


Table 2. Average of maximum, minimum and mean monthly temperatures and rainfall in the municipality of Itápolis, State of São Paulo.

\begin{tabular}{lcccr}
\hline \multirow{2}{*}{ Month } & \multicolumn{3}{c}{ Temperature $\left({ }^{\circ} \mathbf{C}\right)$} & Rainfall \\
\cline { 2 - 4 } & Minimum & Maximum & Mean & $(\mathbf{m m})$ \\
\hline Jan. & 19.5 & 30.9 & 25.2 & 235.9 \\
Feb. & 19.7 & 31.1 & 25.4 & 204.5 \\
Mar. & 19.0 & 30.8 & 24.9 & 158.2 \\
Apr. & 16.4 & 29.5 & 22.9 & 78.9 \\
May & 13.8 & 27.6 & 20.7 & 65.0 \\
June & 12.4 & 26.6 & 19.5 & 43.5 \\
July & 11.9 & 26.9 & 19.4 & 22.9 \\
Aug. & 13.4 & 29.3 & 21.4 & 25.7 \\
Sept. & 15.5 & 30.3 & 22.9 & 70.6 \\
Oct. & 17.1 & 30.6 & 23.9 & 121.2 \\
Nov. & 17.9 & 30.8 & 24.3 & 147.7 \\
Dec. & 19.0 & 30.5 & 24.7 & 242.4 \\
Annual & 16.3 & 29.6 & 22.9 & 1416.5 \\
Minimum & 11.9 & 26.6 & 19.4 & 22.9 \\
Maximum & 19.7 & 31.1 & 25.4 & 242.4 \\
\hline
\end{tabular}

Source: CEPAGRI (2012).

Table 3. Prevalence of infestation by Oestrus ovis according to sheep age in the Central region of the State of São Paulo from July 2009 to February 2010.

\begin{tabular}{ccc}
\hline Age in years & Heads examined/heads infested & Prevalence (\%) \\
\hline $1 \leq$ & $124 / 16$ & 12.9 \\
2 & $8 / 2$ & 25.0 \\
$\geq 3$ & $7 / 1$ & 14.3 \\
Total & $139 / 19$ & 13.7 \\
\hline
\end{tabular}

$\%$ percentage.

was $1416.5 \mathrm{~mm}$ and the average annual temperature for this period was $22.9{ }^{\circ} \mathrm{C}$. No significant correlations were observed between monthly larval numbers and climatic variables, i.e., mean temperature and rainfall $(\mathrm{P}>0.05)$.

Of the total of 85 larvae, $21.2 \%$ was L1, while L2 and L3 represented $37.6 \%$ and $41.2 \%$, respectively. The sheep heads collected were derived mainly from young animals ( $\leq 1$ year old), but the prevalence of $O$. ovis larvae was similar between the age groups (Table 3 ).

\section{Discussion}

The prevalence of $O$. ovis infestation (13.7\%) in this study was lower than those reported in similar studies carried out in other countries such as France, where 65\% of sheep was infested with O. ovis larvae (YILMA; DORCHIES, 1991); or in Sicily, with $55.8 \%$ of prevalence (CARACAPPA et al., 2000); and Turkey, with $40.6 \%$ (ARSLAN et al., 2009). Higher prevalence was also observed in other Brazilian studies: $85.4 \%$ in the south region of the country in sheep exposed to natural infestation for one year (RIBEIRO et al., 1990) and 50\% prevalence in tracer sheep in Botucatu, State of São Paulo, Brazil (SILVA et al., 2012).

Despite the lower prevalence observed in the present study, O. ovis larvae were present in all experimental months, except in
October 2009, coinciding with the lowest number of sheep heads examined. Probably, if more heads had been monthly examined, there would have been greater chances to find infested sheep, as observed in studies carried out in other countries, where sheep are slaughtered in greater amounts and more often. In Sicily, for instance, 70 heads were examined per month (CARACAPPA et al., 2000), whereas in the present study the maximum number of sheep heads examined per month was 26. In the State of São Paulo, Brazil, large slaughterhouses specialized in cattle, poultry and pigs are common; however, the slaughtering of sheep, in general, is restricted to small abattoirs with less often routine, making it difficult to collect a large number of heads to be examined.

Several factors can influence $O$. ovis epidemiology, such as sheep management practices and particular climatic conditions. The low prevalence of oestrosis in these animals may have been influenced by previous treatment with drugs, such as macrocyclic lactones, which are usually used for the prophylaxis of infections by gastrointestinal nematodes and act against $O$. ovis larvae instars (DORCHIES et al., 1996, 1997; LUCIENTES et al., 1998). The influence of anthelmintic treatment in $O$. ovis epidemiology was also observed in Botucatu, where reduction in the infestation of tracer sheep coincided with the treatment of flocks with macrocyclic lactones (SILVA et al., 2012).

Among the climatic factors that influence oestrid fly activity, temperature, light intensity and wind are considered the most important, but in the case of $O$. ovis, temperature is the main factor affecting the larvipositional activity of gravid females (CEPEDA-PALACIOS; SCHOLL, 2000). Although the heads of the slaughtered sheep were examined during each of the eight months, the climatic conditions are likely to be favorable to O. ovis activity throughout the year in the sheep origin region, where the mean of temperature is around $22^{\circ} \mathrm{C}$ and maximum and minimum averages are around 16.3 and $29.6^{\circ} \mathrm{C}$, respectively.

It is noteworthy that mostly $\mathrm{L} 2$ and L3 O. ovis larval instars were recovered in this study. Probably because the climatic conditions were suitable to endogenous larval development and L1 were able to change into L2 in a short period of time. Larvae in sheep head can have a rapid development, reaching maturity in three weeks (COBBETT; MITCHELL, 1941). In the State of Santa Catarina, Brazil, larger L3 numbers were also recovered from tracer sheep (RAMOS et al., 2006), but probably because those animals were exposed to infestation for 28 days and were then housed for 20 more days before slaughter, giving larvae enough time to complete their development.

In conclusion, all different $O$. ovis larvae instars were recovered from the animals slaughtered in this study, which demonstrates the existence of favorable climatic conditions for the fly activity and larval development of $O$. ovis in sheep raised in the Central region of the State of São Paulo.

\section{Acknowledgements}

The authors are grateful to the slaughterhouse workers for their fundamental cooperation during the study. Bruna F. Silva received financial support by FAPESP (Fundação de Amparo à Pesquisa do Estado de São Paulo) and Alessandro F.T. Amarante 
was supported by CNPq (Conselho Nacional de Desenvolvimento Científico e Tecnológico, Brazil).

\section{References}

Alcaide M, Reina D, Frontera E, Navarrete I. Epidemiology of Oestrus ovis (Linneo, 1761) infestation in goats in Spain. Vet Parasitol 2005; 130(3-4): 277-284. PMid:15899552. http://dx.doi. org/10.1016/j.vetpar.2005.03.022

Alcaide M, Reina D, Sánchez J, Frontera E, Navarrete I. Seasonal variations in the larval burden distribution of Oestrus ovis in sheep in the southwest of Spain. Vet Parasitol 2003; 118(3-4): 235-241. PMid:14729171. http://dx.doi.org/10.1016/j.vetpar.2003.09.021

Arslan M, Kara M, Gicik Y. Epidemiology of Oestrus ovis infestations in sheep in Kars province of north-eastern Turkey. Trop Anim Health Prod 2009; 41(3): 299-305. PMid:18523857. http://dx.doi.org/10.1007/ s11250-008-9190-x

Bush AO, Lafferty KD, Lotz JM, Shostak AW. Parasitology meets ecology on its own terms: Margolis et al. revisited. J Parasitol 1997; 83(4): 575-583. PMid:9267395. http://dx.doi.org/10.2307/3284227

Capelle KJ. The occurrence of Oestrus ovis L. (Diptera: Oestridae) in the bighorn sheep from Wyoming and Montana. J Parasitol 1966; 52(3): 618-621. PMid:5942536. http://dx.doi. org/10.2307/3276337

Caracappa S, Rilli S, Zanghi P, Di Marco V, Dorchies P. Epidemiology of ovine oestrosis (Oestrus ovis Linné 1761, Diptera: Oestridae) in Sicily. Vet Parasitol 2000; 92(3): 233-237. http://dx.doi.org/10.1016/S03044017(00)00317-4

Centro de Pesquisas Meteorológicas e Climáticas Aplicadas à Agricultura - CEPAGRI. Clima dos Municipios Paulistas: Itápolis [online]. 2012 [cited 2012 Oct 29]. Available from: http://www.cpa. unicamp.br/outras-informacoes/clima_muni_263.html.

Cepeda-Palacios R, Scholl PJ. Factors affecting the larvipositional activity of Oestrus ovis gravid females (Diptera: Oestridae). Vet Parasitol 2000; 91(1-2): 93-105. http://dx.doi.org/10.1016/S03044017(00)00265-X

Cobbett NG, Mitchell WC. Further observations on the life cycle and incidence of the sheep bot, Oestrus ovis, in New Mexico and Texas. Am $J$ Vet Res 1941; 2: 358-366.

Dorchies P, Alzieu JP, Cadiergues MC. Comparative curative and preventive efficacies of ivermectin and closantel on Oestrus ovis (Linné 1758) in naturally infected sheep. Vet Parasitol 1997; 72(2): 179-184. http:// dx.doi.org/10.1016/S0304-4017(97)00052-6

Dorchies P, Cardinaud B, Fournier R. Efficacy of moxidectin as a $1 \%$ injectable solution and a $0.1 \%$ oral drench against nasal bots, pulmonary and gastrointestinal nematodes in sheep. Vet Parasitol 1996; 65(1-2): 163-168. http://dx.doi.org/10.1016/0304-4017(95)00930-2

Dorchies P, Duranton C, Jacquiet P. Pathophysiology of Oestrus ovis infection in sheep and goats: a review. Vet Rec 1998; 142(18): 487-489. PMid:9612915. http://dx.doi.org/10.1136/vr.142.18.487

Horak IG. Parasites of domestic and wild animals in South Africa. I. Oestrus ovis in sheep. Onderstepoort J Vet Res 1977; 44(2): 55-64. PMid:614524.

Lucientes J, Castillo JA, Ferrer LM, Peribáńez MA, Ferrer-Dufol M, Gracia-Salinas MJ. Efficacy of orally administered ivermectin against larval stages of Oestrus ovis in sheep. Vet Parasitol 1998; 75(2-3): 255-259. http://dx.doi.org/10.1016/S0304-4017(97)00168-4

Oliveira CMB, Oliveira LO, Torres JR. Oestrus ovis larvae distribution in the head of naturally infested sheep. Arq Fac Vet UFRGS 1999; 27(2): 87-92.

Pandey VS. Epidemiology of Oestrus ovis infection of sheep in the highveld of Zimbabwe. Vet Parasitol 1989; 31(3-4): 275-280. http:// dx.doi.org/10.1016/0304-4017(89)90077-0

Papadopoulos E, Chaligiannis I, Morgan ER. Epidemiology of Oestrus ovis L. (Diptera: Oestridae) larvae in sheep and goats in Greece. Small Rumin Res 2010; 89(1): 51-56. http://dx.doi.org/10.1016/j. smallrumres.2009.12.004

Ramos CI, Bellato V, Souza AP, Avila VS, Coutinho GC, Dalagnol CA. Epidemiologia de Oestrus ovis (Diptera: Oestridae) em ovinos no Planalto Catarinense. Cienc Rural 2006; 36(1): 173-178. http://dx.doi. org/10.1590/S0103-84782006000100026

Ribeiro VLS, Oliveira CMB, Branco FPJA. Prevalência e variaçôes mensais das larvas de Oestrus ovis (Linneus, 1761) em ovinos no município de Bagé, RS, Brasil. Arq Bras Med Vet Zootec 1990; 42(3): 211-221.

Silva BF, Bassetto CC, Amarante AFT. Epidemiology of Oestrus ovis (Diptera: Oestridae) in sheep in Botucatu, State of São Paulo. Rev Bras Parasitol Vet 2012; 21(4): 386-90. PMid:23295819. http://dx.doi. org/10.1590/S1984-29612012000400008

Yilma JM, Dorchies P. Epidemiology of Oestrus ovis in southwest France. Vet Parasitol 1991; 40(3-4): 315-323. http://dx.doi.org/10.1016/03044017(91)90111-8

Zumpt P. Myiasis in man and animals in the Old World. London: Butterworths; 1965. PMid:14272962. 